\title{
Correction to: Innovation Effect and Regional Difference of Related Variety: An Empirical Study Based on Prefecture-level City Data of China
}

\section{Yue Huang ${ }^{1} \cdot$ Yangang Fang ${ }^{1} \cdot$ Guofeng Gu$^{1}$}

Published online: 17 September 2021

(c) The Author(s), under exclusive licence to Springer Nature B.V. 2021

\section{Correction to: Applied Spatial Analysis and Policy https://doi.org/10.1007/s12061-021-09404-4}

The original version of this article unfortunately contained missing Funding statement.

The funding statement should be.

Funding The Auspices of MOE (Ministry of Education in China) Project of Humanities and Social Sciences (Project No. 19YJC790043)

The original article has been corrected.

Publisher's Note Springer Nature remains neutral with regard to jurisdictional claims in published maps and institutional affiliations.

The original article can be found online at https://doi.org/10.1007/s12061-021-09404-4.

\section{Yue Huang}

huangy612@nenu.edu.cn

1 School of Geographical Sciences, Northeast Normal University, Changchun 130024, China 